\title{
The Effect of Local Anesthesia (Lidocaine 2\%) with Epinephrine (1:100,000) On Blood Pressure Level of Hypertensive Patients Reported To a Tertiary Care Hospital, Peshawar, Pakistan
}

\author{
Muhammad Ilyas ${ }^{1 *}$, Zupash Ali Khan², Ibrahim Khan², Akif Zamir², Kainat Ijaz² and Jawad Ahmad Kundi ${ }^{3}$ \\ ${ }^{1}$ FCPS Resident Department of Oral \& Maxillofacial Surgery, Sardar Begum Dental College \& Hospital, Pakistan
}

${ }^{2}$ House Officer, Sardar Begum Dental College \& Hospital, Pakistan

${ }^{3}$ Professor\& Head of Department, Oral \& Maxillofacial Surgery, Sardar Begum Dental College \& Hospital, Pakistan

Received: October 30, 2017; Published: November 09, 2017

*Corresponding author: Muhammad Ilyas, FCPS Resident Department of Oral \& Maxillofacial Surgery, Sardar Begum Dental College \& Hospital, Peshawar, Khyber Pukhtunkhwa, Pakistan, Tel: 92-3028809637; Email: Ilyas_khan526@yahoo.com

Abstract

Objective: The objective of the study was to evaluate the effect of local anesthesia (Lidocaine) with epinephrine (1:100000) on blood pressure level and medicine used by hypertensive patients having Prehypertension, stage I and stage II hypertension.

Methodology: This randomized controlled trial study was carried out in the department of Oral and Maxillofacial Surgery, Sardar Begum Dental College, Peshawar, Pakistan from February 2016 to August 2016. A total of 88 male and female hypertensive patients were selected and were divide into two groups through lottery method: Group A: Having 44 patients who receive 3 cartridges of Lidocaine $2 \%$ with epinephrine $(1: 100,000)$.Group B: Having 44 patients who receive 3 cartridges of lidocaine $2 \%$ without epinephrine $(1: 100,000)$. The blood pressure was measured prior to injection, 5minutes after injection, during extraction and after extraction of the tooth. Aspiration was carried out prior to injecting the local anesthesia. Statistical analysis was performed using SPSS 22. P $\leq 0.05$ was considered as significant.

Results: No significant increase in SBP and decrease in DBP were seen 5 minutes after injection, during extraction and after extraction of the tooth. The most commonly medicine taken by patients were $\beta$-blockers $n=42(47.72 \%)$. Pearson correlation revealed that increasing the duration of tooth extraction will decrease SBP (-.204) and DBP (-.106). ANOVA showed that the increase or decrease in SBP and DBP was statistically not significant $(\mathrm{P}=.698)$ between intergroup. Chi-square statistics exhibit that hypertension is highly associated with $40-49$ years age group $(X 2=21.286, P=0.000)$. Regression analysis showed no significant relationship between $\beta$-blockers and local anesthesia with epinephrine 1:100,000.

Conclusion: Three cartridges of local anesthesia with epinephrine 1:100,000 have no significant effect on SBP and DBP in pre-hypertensive, stage-I and stage-II patients.

Key words: Hypertension; Lidocaine; Epinephrine; Blood pressure; Tooth extraction

Abbreviations: SBP: Systolic Blood Pressure; DBP : Diastolic Blood Pressure

\section{Introduction}

Hypertension is the systolic blood pressure (SBP) of $\geq 140 \mathrm{mmHg}$ or diastolic blood pressure (DBP) of $\geq 90 \mathrm{~mm} \mathrm{Hg}$ [1]. More than $90 \%$ of causes of hypertension are not clear but there are certain regulatory systems of blood pressure as well as environmental factors which contribute in regulation of blood pressure [2]. Blood pressure is also regulated by cardiac output and heart rate [3]. Over expression of the genes which controlled these regulatory systems may contribute in high blood pressure [4]. Due to high prevalence of hypertension globally, it is one of the most frequent disease seen in the patients who are visiting the dental hospitals and clinics $[5,6]$. In Pakistan approximately $33 \%$ of adult population suffers from hypertension and is the most common amongst cardiovascular diseases [7].

One utmost apprehension of dental treatment for hypertensive patients is the unexpected and marked increase in blood pressure that could lead to life-threatening complications therefore these 
patients contribute a major risk group in the dental treatment $[5,8]$. Local anesthetics combined with vasoconstrictors are used in most of the dental procedures [9]. Vasoconstrictors in the local anesthesia are added to enhance duration of local anesthesia, to halt systemic toxicity and to assist in hemostasis [10]. The most frequently used local anesthesia in many countries is Lidocaine and it was the first local anesthetic to be marketed in $1948[5,11]$. Epinephrine is the leading vasoconstrictor used in dental practices today $[6,9]$. Epinephrine acts on both $\alpha$ and $\beta$ receptors but dominate on $\beta$. Acting on $\alpha_{1}$ epinephrine causing vasoconstriction in the peripheral blood vessels [12] while increase in the heart rate and blood pressure is due to the effect of epinephrine on $\beta_{1}$ receptors [13].

There is controversy exists among different studies. Some believe that local anesthesia with epinephrine increases blood pressure as well as heart and should be contraindicated in hypertensive patients $[5,11,14,15]$. While some studies showed that the use of local anesthesia with epinephrine has no substantial effect on blood pressure and heart rate when one-three dental catridges are used as the amount of epinephrine is very low [1618]. Daubländer et al. [19] and Meechan et al. [20] demonstrate that it is obligatory for dental professionals to be cautious in proper use of local anesthesia with vasoconstrictor and care is needed when selecting and administrating these anesthetics to avoid systemic complications. The objective of the study is to evaluate the effect of local anesthesia (Lidocaine) with epinephrine (1:100000) on blood pressure level and medicine used by hypertensive patients having Prehypertension, stage I and stage II hypertension.

\section{Methodology}

This randomized controlled trial study was carried out in the department of Oral and Maxillofacial Surgery, Sardar Begum Dental College, Peshawar, Pakistan from February 2016 to August 2016. The ethical approval for this study was taken from the hospital's ethical committee. A cardiologist was on call during the procedure and emergency equipments were arranged. Relaxed atmosphere was provided for the tooth extraction in these patients. All patients were informed about the aim of the study and a well-documented proforma about demography, hypertensive medications and informed consent was taken prior to the procedure. The procedure was performed under the supervision of the head of the department.

A total of 88 male and female hypertensive patients were selected through non-probability purposive sampling using Kelsey formula for clinical trials with a level of significance $\alpha=0.05$, power $=0.80$, prevalence ratio 5.4 and odds ratio 7 .The patients were divided into two groups through lottery method:

a) Group A: Having 44 patients who receive 3 cartridges of lidocaine $2 \%$ with epinephrine $(1: 100,000)$.

b) Group B: Having 44 patients who receive 3 cartridges of lidocaine $2 \%$ without epinephrine $(1: 100,000)$.

The criterion for the stages of hypertension was set as that of American Heart Association [21]. The age selected was 20-70 years,
$\mathrm{SBP} \leq 179$ and $\mathrm{DBP} \leq 110$ and those diagnosed $\geq 6$ months. All those hypertensive patients with other systemic diseases like diabetes mellitus, hepatitis, HIV, immunocompromised, patients undergoing radio or chemotherapy and those who are allergic were excluded from the study. All those were also excluded who were agreed prior to procedure but unwilling to complete it. The blood pressure was measured with a conventional calibrated sphygmomanometer keeping the cuff on the patient's left arm and in supine position, four times during the whole procedure: Prior to injection, 5minutes after injection, during extraction and after extraction of the tooth. Aspiration was carried out prior to injecting the local anesthesia.

Statistical analysis was performed using SPSS 22. One way ANOVA was used for descriptive statistics and intergroup comparisons. Linear regression analysis was used to show the relationship of medicines with hypertension. Chi-square statistics were used for association of age and hypertension. Pearson correlation was applied for relation of hypertension after tooth extraction with time of extraction. $\mathrm{P} \leq 0.05$ was considered as significant (Table 1).

Table 1: Stages of Hypertension.

\begin{tabular}{|c|c|c|c|}
\hline $\begin{array}{c}\text { Blood Pressure } \\
\text { Category }\end{array}$ & $\begin{array}{c}\text { Systolic mm Hg } \\
\text { (upper \#) }\end{array}$ & and & less than 80 \\
\hline Normal & less than 120 & or & $80-89$ \\
\hline Prehypertension & $120-139$ & or & $90-99$ \\
\hline $\begin{array}{c}\text { High Blood } \\
\text { Pressure } \\
\text { (Hypertension) } \\
\text { Stage 1 }\end{array}$ & $140-159$ & or & 100 or higher \\
\hline $\begin{array}{c}\text { High Blood } \\
\text { Pressure } \\
\text { (Hypertension) } \\
\text { Stage 2 }\end{array}$ & 160 or higher & or & Higher than 110 \\
\hline $\begin{array}{c}\text { Hypertensive } \\
\text { Crisis } \\
\text { (Emergency care } \\
\text { needed) }\end{array}$ & Higher than 180 & & \\
\hline
\end{tabular}

\section{Results}

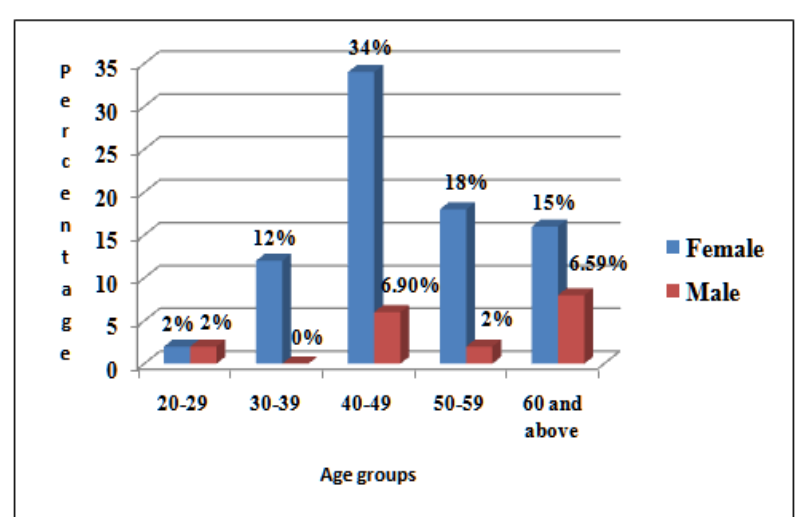

Figure 1: Percentages of hypertensive patients according to the age groups.

The mean age presented was $39.4 \pm 15.8$ years. The female to male ratio was $3.88: 1$. The results of medicines taken by 
hypertensive patients and age groups involved are shown in Table 2 and Figure 1 respectively. The mean SBP and DBP prior and after tooth extraction is shown in Table 3. The effect of duration of procedure with SBP and DBP prior to local anesthesia with and without epinephrine $(1: 100,000)$ injection and after tooth extraction is shown in the Figure 2 and Figure 3 respectively which exhibit that SBP decreases when operator increases the time of tooth extraction while there is no such variation exists in DBP with time. When Pearson correlation was applied it also revealed that the duration of tooth extraction has negative correlation on SBP (-.204) and DBP (-.106). ANOVA when applied for intergroup comparison disclosed that the increase or decrease in SBP and DBP were statistically not significant $(\mathrm{P}=.698)$. Chi-square statistics exhibit that hypertension was highly associated with 40-49 years aged group ( $\mathrm{X} 2=21.286, \mathrm{P}=0.000)$.

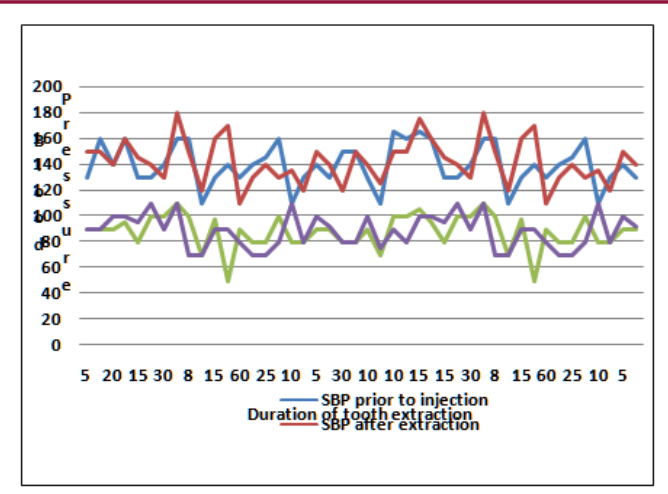

Figure 2: SBP and DBP prior to local anesthesia with epinephrine injection and after tooth extraction with time taken to complete the procedure.

Table 2: Different medicines used by hypertensive patients

\begin{tabular}{|c|c|c|c|c|c|c|c|}
\hline \multicolumn{8}{|c|}{ Epinephrine } \\
\hline & $\beta$-blocker & $\begin{array}{l}\text { Angiotensin } \\
\text { receptor } \\
\text { blockers(ARBs) }\end{array}$ & $\begin{array}{l}\text { Angiotensin } \\
\text { converting } \\
\text { enzyme(ACE) } \\
\text { inhibitors }\end{array}$ & $\begin{array}{l}\text { Ca-channel } \\
\text { blockers }\end{array}$ & As card & $\begin{array}{l}\text { Nil (Not using } \\
\text { any medicines) }\end{array}$ & Total \\
\hline Female & $22(50 \%)$ & $3(6.81 \%)$ & $2(4.54 \%)$ & 0 & $3(6.81 \%)$ & $6(13.63 \%)$ & $36(81.82 \%)$ \\
\hline Male & $4(9.09 \%)$ & 0 & $2(4.54 \%)$ & $2(4.54 \%)$ & 0 & 0 & $8(18.18 \%)$ \\
\hline Total & $26(59.09 \%)$ & $3(6.81 \%)$ & $4(9.09 \%)$ & $2(4.54 \%)$ & $3(6.81 \%)$ & $6(13.63 \%)$ & $44(100 \%)$ \\
\hline \multicolumn{8}{|c|}{ Without Epinephrine } \\
\hline & $\beta$-blocker & $\begin{array}{l}\text { Angiotensin } \\
\text { receptor } \\
\text { blockers(ARBs) }\end{array}$ & $\begin{array}{l}\text { Angiotensin } \\
\text { converting } \\
\text { enzyme(ACE) } \\
\text { inhibitors }\end{array}$ & $\begin{array}{l}\text { Ca-channel } \\
\text { blockers }\end{array}$ & As card & $\begin{array}{l}\text { Nil (Not using } \\
\text { any medicines) }\end{array}$ & Total \\
\hline Female & $12(27.27 \%)$ & 0 & $4(9.09 \%)$ & $6(13.64 \%)$ & 0 & $12(27.27 \%)$ & $34(77.27 \%)$ \\
\hline Male & $4(9.09 \%)$ & $4(9.09 \%)$ & 0 & 0 & 0 & $1(4.54 \%)$ & $10(22.72 \%)$ \\
\hline Total & $16(36.36 \%)$ & $4(9.09 \%)$ & $4(9.09 \%)$ & $6(13.64 \%)$ & & $7(31.81 \%)$ & $44(100 \%)$ \\
\hline
\end{tabular}

Table 3: Mean Systolic blood pressure (SBP) and Diastolic blood pressure (DBP) before and after tooth extraction with $\mathrm{P}$ value $(\leq 0.05)$.

\begin{tabular}{|c|c|c|c|c|c|c|}
\hline & With & Epinephrine & & Without & Epinephrine & \\
\hline & $\begin{array}{l}\text { Mean (Prior to } \\
\text { local anesthesia } \\
\text { injection) }\end{array}$ & $\begin{array}{c}\text { Mean (After } \\
\text { extraction of tooth) }\end{array}$ & $\mathrm{P}$ value $(\leq 0.05)$ & $\begin{array}{l}\text { Mean (Prior to } \\
\text { local anesthesia } \\
\text { injection) }\end{array}$ & $\begin{array}{c}\text { Mean (After } \\
\text { extraction of tooth) }\end{array}$ & $P$ value $(\leq 0.05)$ \\
\hline \multirow{2}{*}{$\begin{array}{c}\text { Pre-hypertension } \\
\text { SBP } \\
\text { DBP }\end{array}$} & $131.50 \pm 2.82$ & $127.14 \pm 5.67$ & 0.769 & $131.20 \pm 9.57$ & $131.98 \pm 11.13$ & 0.747 \\
\hline & $82.14 \pm 2.67$ & $80.00 \pm 0.00$ & 0.505 & $84.76 \pm 6.11$ & $84.04 \pm 2.97$ & 0.824 \\
\hline \multirow{2}{*}{$\begin{array}{l}\text { Stage I } \\
\text { SBP } \\
\text { DBP }\end{array}$} & $143.13 \pm 4.58$ & $145.45 \pm 4.98$ & 0.657 & $143.18 \pm 4.62$ & $146.50 \pm 5.80$ & 0.719 \\
\hline & $91.78 \pm 2.94$ & $90.78 \pm 1.72$ & 0.821 & $91.33 \pm 2.14$ & $90.60 \pm 1.34$ & 0.566 \\
\hline \multirow{2}{*}{$\begin{array}{l}\text { Stage II } \\
\text { SBP } \\
\text { DBP }\end{array}$} & $164.00 \pm 6.15$ & $166.67 \pm 7.53$ & 0.695 & $165.30 \pm 5.35$ & $166.67 \pm 2.89$ & 0.891 \\
\hline & $103.12 \pm 3.72$ & $102.86 \pm 4.87$ & 0.649 & $101.42 \pm 3.78$ & $103.00 \pm 4.38$ & 0.986 \\
\hline
\end{tabular}

The mean SBP was $147.50 \pm 17.29$. At a constant level of SBP(140.00) there will be 5.882 increase occurred in after 5 minutes of LA with epinephrine and were statistically significant $(\mathrm{P}=.04)$. When the relation of $\beta$-blockers and epinephrine was evaluate the increase was same but statistically not significant
$(\mathrm{P}=$.737).The mean DBP after 5 minutes of local anesthesia with epinephrine was $89.29 \pm 12.07$. There was no increase or decrease seen. While in patients using $\beta$-blockers, DBP increased by 3.84 and is statistically insignificant $(\mathrm{P}=.772)$. 


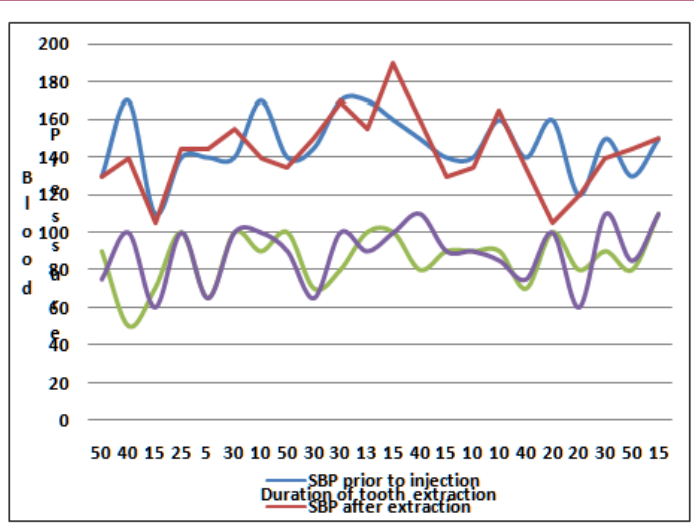

Figure 3: SBP and DBP prior to local anesthesia without epinephrine injection and after tooth extraction with time taken to complete the procedure.

The mean SPB was $143.57 \pm 17.15$. There will be 5.717 increase occur in SPB with medications and was statistically significant $(\mathrm{P}=.026)$. The mean DBP was $90.71 \pm 10.86$. Medications will not affect DBP ( $\mathrm{P}=.984)$ during tooth extraction. The mean SBP after tooth extraction was $143.57 \pm 17.15$. The relationship of medication with hypertension showed that there will be 6.583 increase and is highly significant $(\mathrm{P}=.009)$. When $\beta$-blockers were related the increase will be 10.58 but statistically not significant $(\mathrm{P}=.536)$. The mean DBP was $88.64 \pm 12.32$. The increase in DBP is statistically not significant for medications $(\mathrm{P}=.073)$ as well as for $\beta$-blockers $(\mathrm{P}=.218)$. Regression analysis also showed that those who are taking medications early morning results in decrease of SBP $(-2.22)$ and DBP $(-1.64)$ but the decrease is not significant $(\mathrm{P}=.749)$ and $(\mathrm{P}=.742)$ respectively.

\section{Discussion}

This study not only focuses on the effect of LA with epinephrine on the blood pressure level of hypertensive patients butalso interpret the relationship of medication used by hypertensive patients and especially $\beta$-blockers with SBP and DBP. Furthermore, the study described the correlation of duration of tooth extraction with SBP and DBP. The study revealed that the most frequently medicines used by hypertensive patients were $\beta$-blockers $n=42(47.72 \%)$ and the most dominant gender involved was female. The female to male ratio was 3.88:1 showing high prevalence in females. Silvestre et al. [22]. showed that angiotensin II receptor antagonist were the most frequently used medicine by hypertensive patients and prevailed a ratio of 1.9:1 between female and male patients.

The present study noted that there was a decrease occur in DBP of pre-hypertensive, stage-I and stage-II hypertensive patients by $1.90 \mathrm{~mm} \mathrm{Hg}$ while SBP increases in all these patients by $2.54 \mathrm{~mm}$ $\mathrm{Hg}$. But the increase in SBP and decrease in DBP were statistically insignificant. Chaudhry et al. [23] demonstrate that the mean DBP after extraction decreases after tooth extraction which harmonize with results of the current study while there was significant increase seen in the mean SBP of stage-II hypertensive patients $(21 \mathrm{mmHg})$ after extraction which contradict this study. The decrease seen in the mean DBP of the present study matches the results of the study done by Abu-Mustafa et al. [24], Silvestre et al. [22] proclaim no significant changes in SBP and DBP while determining at three time points in those patients who received local anesthesia with vasoconstrictors which support this study. Ogunlewe et al. [25] conducted a study on two groups, one received Lidocaine $2 \%$ with epinephrine 1:80,000 while other group received plain Lidocaine $2 \%$. After administration of anesthesia no significant difference was observed between these groups however, a significant difference was seen during tooth extraction in both groups which contradict present study.

The current study revealed that no adverse effect was reported in those patients who were using $\beta$-blockers. The changes in the mean SBP and DBP after 5 minutes of anesthesia with epinephrine, during and after extraction were insignificant in these patients however Hersh et al. [26] observed a significant interaction between $\beta$-blockers and epinephrine when Lidocaine with epinephrine 1:100,000 was used. This study also found that increasing the tooth extraction time will results in decreasing SBP and DBP. The limitation of this study is its small sample size. Apart from its small sample size the study demonstrate a thorough evaluation of the effect of local anesthesia with vasoconstrictor on the blood pressure level. The effect of duration of tooth extraction, use of 03 cartridges and patients using $\beta$-blockers in the sample size are idiosyncratic to this study. However, the results cannot be anticipated for the true estimation within the general population. The future study may be to concentrate the effect of local anesthesia with vasoconstrictor in patients using $\beta$-blockers with large sample size.

\section{Conclusion}

The findings of present study concluded that use of three cartridges of local anesthesia with epinephrine 1:100,000 have no significant effect on SBP and DBP in pre-hypertensive, stage-I and stage-II patients provided to prevent accidental intravascular injection.

\section{Acknowledgment}

We are thankful to Dr.Alam Khan for his assistance who were on call Cardiologist, working in CCU, Khyber Teaching Hospital, Peshawar, Pakistan.

\section{References}

1. McGill M (2016) Hypertension: causes, symptoms and treatment.

2. Oparil S, Zaman MA, Calhoun DA (2003) Pathogenesis of hypertension. Ann Intern Med 139(9): 761-776.

3. Carretero OA, Suzanne O (2000) Essential hypertension Part 1 definition and etiology. Circulation 101(3): 329-335.

4. Aziz KU (2015) Evolution of Systemic Hypertension in Pakistani Population. J Coll Physicians Surg Pak 25(4): 286-291.

5. Matsumura K, Miura K, Takata Y, Kurokawa H, Kajiyama M, et al. (1998) Changes in blood pressure and heart rate variability during dental surgery. Am J Hypertens 11(1): 1376-1380.

6. Gungormus M, Buyukkurt MC (2003) The evaluation of the changes in blood pressure and pulse rate of hypertensive patients during tooth extraction. Acta Med Austriaca 30(5): 127-129.

7. Safdar NF, Bertone-Johnson ER, Cordeiro L, Jafar TH, Cohen NL (2015) Dietary patterns and their association with hypertension among Pakistani urban adults. Asia Pac J Clin Nutr 24(4): 710-719. 
8. Jowett NI, Cabot LB (2000) Patients with cardiac disease: considerations for the dental practitioner. Br Dent J 189(6): 297-302.

9. Haas DA (2002) An update on local anesthetics in dentistry. J Can Dent Assoc 68: 546-551.

10. Malamed SF (2004) Handbook of Local Anesthesia ( $5^{\text {th }}$ edn). St Louis, Mo: Elsevier Mosby 41: 149-151.

11. Malamed SF, Gagnon S, Leblanc D (2000) A comparison between articaine $\mathrm{HCl}$ and lidocaine $\mathrm{HCl}$ in pediatric dental patients. Pediatr Dent 22(4): 307-311.

12. Brown RS, Rhodus NL (2005) Epinephrine and local anesthesia revisited. Oral Surg Oral Med Oral Pathol Oral Radiol Endod 100(4): 401-408.

13. Cecanho R, De Luca LA, Ranali J (2006) cardiovascular effects of felypressin. Anesth Prog 53(4): 119-125.

14. Sierra Rebolledo A, Delgado Molina E, BeriniAytís L, Gay Escoda C (2007) Comparative study of the anesthetic efficacy of $4 \%$ articaine versus $2 \%$ lidocaine in inferior alveolar nerve block during surgical extraction of impacted lower third molars. Med Oral Patol Oral Cir Bucal 12: 139-144.

15. Nagata T, Mishima Y, Sawada M, Hiraki T, Hamada N, et al. (2010) Anesthetic management of a patient with deteriorated cardiac function following cardiopulmonary resuscitation. Kurume Med J 57(3): 81-84.

16. Silvestre FJ, Verdú MJ, Sanchis JL, Grau D, Peñarrocha M (2001) Effects of vasoconstrictors in dentistry upon systolic and diastolic arterial pressure. Med Oral 6(1): 57-63.

17. Faraco FN, Armonia PL, Simone JL (2003) Assessment of cardiovascular parameters during dental procedures under the effect of benzodiazepines: A double blind study. Braz Dent J 14(3): 215-219
18. Faraco FN, Armonia PL, Sendyk WR (2004) Analysis of anesthetic efficacy between $2 \%$ to $3 \%$ related to subject stress [in Portuguese]. Rev Bras Odontol 6: 8-11.

19. Daubländer M, Müller R, Lipp MD (1997) The incidence of complications associated with LA in dentistry. Anesth Prog 44(4): 132-141.

20. Meechan JG, Cole B, Welbury RR (2001) The influence of two different dental local anesthetic solutions on the hemodynamic responses of children undergoing restorative dentistry: A randomized, single-blind, split-mouth study. Br Dent J 190: 502-504.

21.(2016) American Heart Association. Understanding Blood Pressure Readings.

22. Silvestre FJ, Salvador-Martínez I, Bautista D, Silvestre-Rangil J (2011) Clinical study of hemodynamic changes during extraction in controlled hypertensive patients. Med Oral Patol Oral Cir Bucal 16(3): e354-e358.

23. Chaudhry S, Iqbal HA, Izhar F, Mirza KM, Khan NF, et al. (2011) Effect on blood pressure and pulse rate after administration of an epinephrine containing dental local anaesthetic in hypertensive patients. J Pak Med Assoc 61(11): 1088-1091.

24. Abu-Mustafa N, Aldawssary A, Assari A, Alnujaidy S, Almutlaq A (2015) A prospective randomized clinical trial compared the effect of various types of local anesthetics cartridges on hypertensive patients during dental extraction. J Clin Exp Dent 7(1): e84-e88.

25. Ogunlewe MO, James O, Ajuluchukwu JN, Ladeinde AL, Adeyemo WL, et al. (2011) Evaluation of haemodynamic changes in hypertensive patients during tooth extraction under local anesthesia. West Indian Med J 60(1): 91-95.

26. Hersh EV, Giannakopoulos H (2010) Beta-adrenergic blocking agents and dental vasoconstrictors. Dent Clin North Am 54(4): 687-696. 